\title{
Effectiveness of Inqury Discussion assisted Implementation of Powerpoint Media in Life Organization in SMP N I Pulokulon
}

\section{Efektivitas Diskusi Inkuiri berbantuan Media Powerpoint pada Materi Organisasi Kehidupan di SMP N I Pulokulon}

\author{
Muhamad Jalil \\ Prodi Tadris Biologi Jurusan Tarbiyah IAIN Kudus \\ Jalan Conge Ngembalrejo Kotak Pos 51 Kecamatan Bae Kudus \\ muhamadjalil@stainkudus.ac.id
}

\begin{abstract}
Biology Learning at SMP N 1 Pulokulon obtained information that the learning process that occurs less involving students. The final test of the first semester for the science subjects was $35.5 \%$ of the students got the score $\geq 50$, the students' learning completeness for the Biology subject in the school was $65 \%$ of students got $\geq 50$. The effort to solve the problem was by applying inquiry discussion. This method is combined with PowerPoint media that can display images concretely. This study aims to determine the effectiveness of inquiry discussion assisted application of PowerPoint media in the learning of organizational life on students in SMP N 1 Pulokulon. The type of data consists of: (1) affective and psychomotoric students, obtained by using activity observation sheet and student performance during the learning progress, (2) cognitive students, obtained by multiple choice test given at the beginning and end of learning. Achievement mastery of affective and psychomotor learning result that is $\geq 85 \%$ student reach good and very good criterion. Analysis of cognitive data of students using variance analysis, if the $F$ test is significantly different then continued the test of the BNT. The BNT test result in the post test shows that the experimental class is significantly different from the comparison class. Thus it can be concluded that the inquiry discussion with PowerPoint media effectively applied to the material organization of life in students in class VII SMP N 1 Pulokulon.
\end{abstract}

Keywords: Inquiry Discussion, Organization of Life, Powerpoint Media

\section{PENDAHULUAN}

Pembelajaran biologi mengkaji berbagai persoalan yang berkait dengan berbagai fenomena mahluk hidup pada berbagai tingkat organisasi kehidupan. Objek biologi berupa makhluk hidup dari level seluler sampai level biosfer. Biologi selalu menjadi pembelajaran menarik karena objek kajian sangat mudah ditemui di sekitar sekolah dan 
rumah. Guru tidak kehilangan akal untuk selalu menghadirkan suasana kelas yang interaktif, menantang, dan dan memacu inkuiri siswa.

Guru hendaknya melibatkan siswa dalam proses belajar mengajar. Pembelajaran model teacher oriented berakibat pada keaktifan siswa dalam belajar kurang dan hasil belajarnya tidak maksimal. Hasil tes akhir semester satu untuk mata pelajaran IPA Biologi di SMP Negeri 1 Pulokulon Kabupaten Grobogan diperoleh 35,5\% siswa memperoleh nilai $\geq 50$. Ketuntasan yang diharapkan pada mata pelajaran Biologi $65 \%$ siswa memperoleh nilai $\geq 50$.

Pengetahuan yang rendah ini bias jadi keterlibatan siswa dalam proses pembelajaran belum maksimal. Guru perlu menggali kemampuan siswa dalam menyelidiki, analisis, inkuiri dan komunikasi dalam pembelajaran Biologi. Proses sains tersebut sebagai upaya guru untuk menuntun siswa dalam menemukan konsep-konsep pengetahuan sendiri, sehingga pengetahuan yang diperoleh lebih terekam lebih lama.

Metode diskusi inkuiri adalah cara pembelajaran dengan memunculkan masalah dimana siswa didorong dan dirangsang mencari jawaban permasalahan secara berkelompok sehingga menemukan pengetahuan sendiri. Selain berpusat pada siswa, metode ini memiliki keunggulan lain yaitu dapat membentuk konsep diri (self concept) sehingga terbuka terhadap pengalaman-pengalaman baru, lebih kreatif, berkeinginan untuk selalu mengambil kesempatan yang ada. Implementasi pembelajaran semacam inkuiri telah berhasil menunjukkan peningkatan penguasaan aspek kognitif siswa secara signifikan (Abdurrahman, 2017).

Diskusi inkuiri dapat dikombinasikan dengan media yang membantu guru dalam menyampaikan konsep organisasi kehidupan. Konsep materi organisasi kehidupan bersifat abstrak. Pada materi ini banyak dikaji mengenai struktur benda benda kecil misalkan sel, jaringan, organ dan sistem organ. Siswa merasa sulit menemukan konsepkonsep yang nyata pada materi organisasi kehidupan, sehingga dengan bantuan media akan lebih memperkuat proses menemukan konsep sel, jaringan, organ dan sistem organ.

Salah satu media yang diharapkan dapat membantu siswa menangkap konsep yang abstrak adalah media PowerPoint. Media ini dapat menampilkan berbagai macam gambar dan data secara jelas (Jalil, 2016). Power Point cocok untuk menyampaikan materi pada kelas besar. Berdasarkan hasil observasi kelas, kelas eksperimen termasuk kelas besar yaitu dengan rata-rata 52 siswa. Hal ini dikuatkan dengan tersedianya sarana 
prasarana yang cukup memadai di SMPN 1 Pulokulon. Pengoperasian media PowerPoint dibutuhkan perangkat seperti laptop, dan Liquid Crystal Display (LCD).

Berdasarkan permasalahan yang telah dipaparkan dengan renak-renik sebab dan akibat, maka perlu dilakukan penelitian dengan judul "Efektivitas Diskusi Inkuiri disertai Penerapan Media PowerPoint pada Materi Organisasi Kehidupan di SMP N I Pulokulon". Tujuan penelitian ini adalah mengetahui efektivitas diskusi inkuiri disertai penerapan media PowerPoint dalam pembelajaran materi organisasi kehidupan pada siswa di SMP N 1 Pulokulon.

\section{METODE PENELITIAN}

Penelitian ini telah dirancang dengan pendekatan eksperimen menggunakan Comparison Groub Design. Populasi penelitian ini berjumlah 4 kelas yang terdiri dari kelas VII B, VII E, VII F, dan VII G. Populasi penelitian ini dijadikan sebagai sampel penelitian dengan pertimbangan kelas tersebut diajar oleh guru yang sama dan homogen. Tiga kelas yang menjadi kelas eksperimen masing-masing berjumlah 52 untuk VII E (E1), 51 untuk VII F (E-2), dan 52 untuk VII G (E-3), sedangkan VII B (kelas pembanding) berjumlah 52. Variabel bebas berupa pembelajaran Biologi pada materi organisasi kehidupan dengan diskusi inkuiri disertai media PowerPoint. Variabel terikat berupa ranah afektif, psikomotorik, aktivitas, hasil belajar kognitif siswa.

Aspek kognitif diukur menggunakan tes pilihan ganda. Penilaian yang digunakan untuk mendapatkan ranah afektif dan psikomotorik siswa adalah skala lima. Uji normalitas digunakan untuk mengetahui apakah data yang diperoleh normal atau tidak. Bila data penelitian normal berarti penelitian yang telah dilakukan dapat dipertanggung jawabkan secara ilmiah (Sudjana, 1998). Uji kesamaan dua varians ini bertujuan untuk mengetahui variansi dari dua kelompok, apakah mempunyai variansi yang sama atau tidak (Sudjana, 1998). Analisis varians digunakan untuk menguji hipotesis komparatif rata-rata $\mathrm{k}$ sampel bila datanya berbentuk interval atau ratio. Apabila uji $\mathrm{F}$ berbeda signifikan maka untuk mengetahui perbedaan antar perlakuan, dilakukan uji Beda Nyata Terkecil (BNT). 


\section{HASIL PENELITIAN DAN PEMBAHASAN}

\section{Hasil Penelitian}

Berdasarkan penelitian yang telah dilaksanakan di SMP N 1 Pulokulon, diperoleh data penelitian meliputi ranah afektif, psikomotorik, dan kognitif siswa pada materi organisasi kehidupan. Ranah afektif merupakan penilaian yang mengarah pada sikap siswa. Data ini diambil dengan teknik observasi. Hasil pengamatan sikap siswa disajikan pada Tabel 1.

Tabel 1 Ranah Afektif Siswa Kelas E-1, E-2 dan E-3

\begin{tabular}{ccccccc}
\hline \multirow{2}{*}{ Kriteria } & \multicolumn{7}{c}{ Jumlah siswa } & Persentase & & \\
& E1 & E2 & E3 & E1 & E2 & E3 \\
\hline Sangat baik & 26 & 22 & 27 & $50 \%$ & $43,14 \%$ & $51,92 \%$ \\
Baik & 20 & 23 & 18 & $38,46 \%$ & $45,10 \%$ & $34,62 \%$ \\
Cukup baik & 2 & 4 & 5 & $3,85 \%$ & $7,84 \%$ & $9,62 \%$ \\
Kurang baik & 3 & 1 & 2 & $5,77 \%$ & $1,96 \%$ & $3,85 \%$ \\
Tidak baik & 1 & 1 & 0 & $1,92 \%$ & $1,96 \%$ & $0,00 \%$ \\
\hline
\end{tabular}

Psikomotorik merupakan kompetensi yang wajib dimiliki siswa menyangkut keterampilan baik hard maupun soft. Dengan demikian siswa akan lebih siap menghadapi tantangan kehidupan kedepan. Data belajar psikomotorik siswa diambil pada waktu siswa melakukan diskusi, presentasi, dan kegiatan inkuir, sehingga datanya dapat dilihat pada Tabel 2.

Tabel 2 Ranah Psikomotorik Siswa Kelas E-1, E-2 dan E-3

\begin{tabular}{ccccccc}
\hline \multirow{2}{*}{ Kriteria } & \multicolumn{7}{c}{ Jumlah siswa } & Persentase & & \\
& E1 & E2 & E3 & E1 & E2 & E3 \\
\hline Sangat baik & 9 & 14 & 18 & $17,31 \%$ & $27,45 \%$ & $34,62 \%$ \\
Baik & 36 & 30 & 26 & $69,23 \%$ & $58,82 \%$ & $50,00 \%$ \\
Cukup baik & 4 & 4 & 5 & $7,69 \%$ & $7,84 \%$ & $9,62 \%$ \\
Kurang baik & 2 & 2 & 2 & $3,85 \%$ & $3,92 \%$ & $3,85 \%$ \\
Tidak baik & 1 & 1 & 1 & $1,92 \%$ & $1,96 \%$ & $1,92 \%$ \\
Total & 52 & 51 & 52 & $100 \%$ & $100 \%$ & $100 \%$ \\
\hline
\end{tabular}

Hasil belajar kognitif siswa lebih menekankan aspek kemampuan pengetahuan seseorang. Hasil belajar ini diambil melalui dengan metode tes berupa soal pilihan ganda. Tes yang dipakai untu analisis varians adalah tes setelelah pembelajaran. Perhitungan analisis varians satu arah pada hasil postes siswa ditunjukkan pada Tabel 3. 
Tabel 3 Perhitungan Analisis Varians Satu Arah pada Hasil Postes Siswa

\begin{tabular}{ccccccc}
\hline No & $\begin{array}{c}\text { Sumber } \\
\text { variasi }\end{array}$ & Dk & $\begin{array}{c}\text { Jumlah } \\
\text { Kuadrat }\end{array}$ & MK & F hit & T tab \\
\hline 1 & Total & 206 & 33893,6 & - & & \\
2 & $\begin{array}{c}\text { Antar } \\
\text { Kelompok } \\
\text { Dalam }\end{array}$ & 3 & 1853,1 & 617,7 & 3,9 & 2,6 \\
3 & kelompok & 203 & 32040,5 & 157,8 & & \\
& & & &
\end{tabular}

Pemaparan pada Tabel 3 diperoleh perhitungan Anava antar kelompok berupa nilai Fhitung $=3,9>$ nilai $\mathrm{F}_{\text {tabel }}=2,6(\alpha=0,05)$, maka secara statistik Ho ditolak dan $\mathrm{Ha}$ diterima artinya diskusi inkuiri disertai penerapan media PowerPoint berpengaruh terhadap hasil belajar kognitif. Berikutnya untuk mengetahui perbedaan nilai-nilai ratarata hasil belajar kognitif antar kelas maka dilanjutkan dengan uji BNT antar kelompok eksperimen 1, 2, 3, dan kelompok pembanding. Hasil yang diperoleh adalah disajikan pada Tabel 4.

Tabel 4 Perhitungan Uji Bnt pada Hasil Post Test Siswa

\begin{tabular}{cccccccc}
\hline No & Rata-rata & $\begin{array}{c}\text { Selisih } \\
\text { Rata- } \\
\text { Rata }\end{array}$ & E-2 & E-3 & E-1 & $P$ & BNT 5\% \\
\hline 1 & 69,3 & E-2 & - & - & - & - \\
2 & 65,7 & E-3 & 3,6 & - & - & - & \\
3 & 63,3 & E-1 & $5,9^{*}$ & 2,3 & - & - & \\
4 & 54,1 & $P$ & $15,2^{*}$ & $11,6^{*}$ & $9,3^{*}$ & - & \\
\hline
\end{tabular}

Uji BNT di atas berarti antara kelas eksperimen 1, 2, dan 3 dengan kelas pembanding berbeda nyata. Untuk kelas eksperimen 2 dengan kelas eksperimen 3 tidak berbeda nyata, kelas eksperimen 1 dengan kelas eksperimen 2 berbeda nyata, dan kelas eksperimen 1 dengan kelas eksperimen 3 tidak berbeda nyata.

Berdasarkan hasil analisis terhadap angket yang diberikan kepada siswa sebelum pembelajaran 137 dari 155 siswa merasa senang. Pengakuan siswa terhadap pembelajaran Biologi merupakan ilmu yang mempelajari lingkungan sekitar (alam), sehingga kajiannya sangat dekat dengan keseharian siswa. Selain itu adanya media Powerpoint membantu memahamkan siswa dalam mengkaji sebagian materi organisasi kehidupan yang bersifat abstrak. Persentase respon senang terhadap pembelajaran 
biologi dengan metode diskusi inkuiri disertai penerapan media Powerpoint dilukiskan pada Gambar 1.

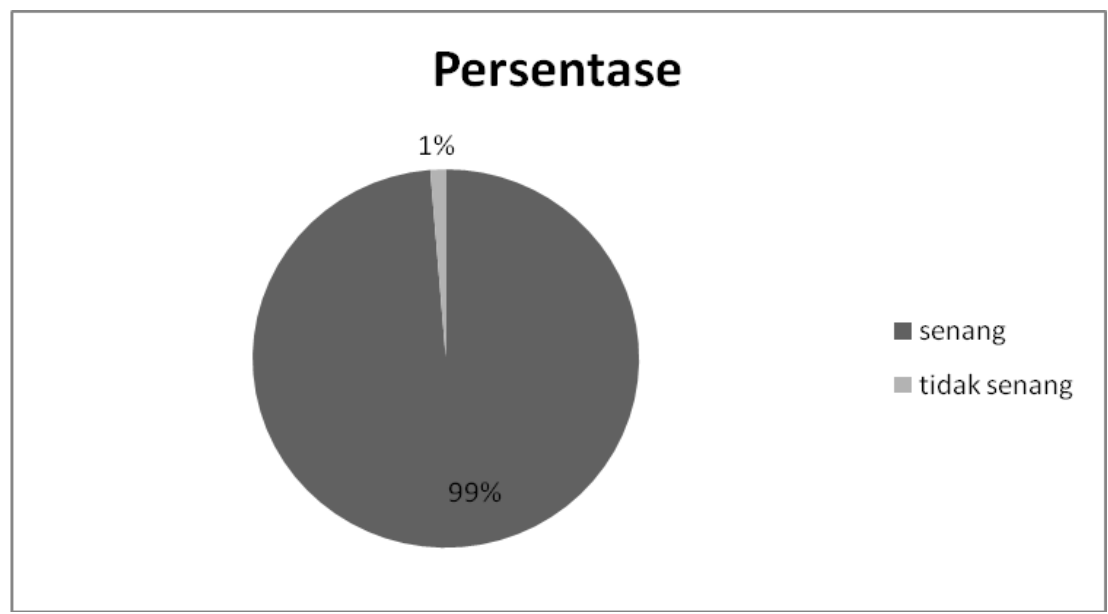

Gambar 1 Respon Siswa Setelah Pembelajaran

\section{Pembahasan}

Pelaksanaan penelitian pada materi organisasi kehidupan, kelas eksperimen mendapat perlakuan dengan diskusi inkuiri disertai media PowerPoint, dan kelas pembanding tidak mendapatkan perlakuan tertentu, maksudnya selama proses pembelajarannya hanya dengan menggunakan metode yang biasa digunakan oleh guru mata pelajaran Biologi di sekolah.

Pada pelaksanaan pembelajaran dengan diskusi inkuiri disertai penerapan media PowerPoint pada kelompok eksperimen (VII E, VII F, VII G). Proses pembelajaran dimulai dengan memberikan apersepsi berupa pertanyaan-pertanyaan yang berhubungan dengan materi yang berkaitan dengan fenomena atau kejadian dalam kehidupan seharihari siswa untuk memusatkan perhatian siswa kepada materi yang akan diajarkan.

Setelah siswa termotivasi dalam belajar pada tahap awal, maka selanjutnya guru mengingatkan agar Lembar Diskusi Siswa (LDS) yang sudah dikerjakan secara individu di rumah bisa didiskusikan dengan anggota kelompoknya. Siswa akan mudah memahami konsep organisasi kehidupan yang sulit jika LDS yang sebelumnya dibagikan oleh guru dikerjakan dengan baik. Kegiatan diskusi akan terjalin komunikasi dan interaksi dimana siswa dalam satu kelompok saling berbagi pendapat atau ide serta memberi kesempatan siswa untuk mengungkapkan pendapatnya. Hal ini seseuai pendapat Jalil (2018), diskusi dapat meningkatkan aktivitas oral terutama berkomunikasi antar guru dan siswa. Di sisi 
lain terdapat beberapa kendala disebabkan ada kelompok yang belum siap dengan jawaban LDS, yang pada akhirnya pada tahap presentasi berubah urutannya.

Tahap berikutnya siswa menyampaikan hasil diskusi melalui kegiatan presentasi. Setelah melakukan presentasi, kelompok yang di belakang berhak mengajukan pertanyaan kepada kelompok yang di depan. Kelompok di depan juga berhak mengajukan pertanyaan kepada audien. Saat siswa melakukan diskusi atau sesi tanya jawab, siswa terkondisi untuk bertanya, menjawab pertanyaan, mengemukakan pendapat dan memberi tanggapannya. Guru melakukan evaluasi hasil diskusi, meluruskan konsep jika ada penyampaian konsep yang salah oleh siswa, kemudian guru memberikan penguatan materi terhadap hasil diskusi siswa dengan media PowerPoint. Media sebagai alat bantu pembelajaran selain berfungsi untuk menjelaskan materi juga untuk menarik minat siswa sehingga mendorong warga belajar untuk mencintai ilmu pengetahuan dan gemar mencari sendiri sumber-sumber ilmu pengetahuan (Sujarwo, 2013, pp. 68-72).

Penilaian afektif dilakukan dua kali yang kemudian dirata-rata hasilnya sebagai nilai akhir. Penilaian pertama dilakukan pada saat membahas mengenai sel dan jaringan, adapun yang menjadi aspek penilaiannya adalah (1) kesiapan siswa sebelum mengikuti pembelajaran; (2) kerapian siswa selama pembelajaran (3) keaktifan siswa selama pembelajaran berlangsung, (4) Sikap siswa terhadap teman yang membutuhkan; (5) tanggung jawab dalam mengerjakan soal (tugas) yang diberikan dan (6) melakukan aktivitas lain yang tidak mendukung proses pembelajaran. Penilaian kedua dilakukan pada saat siswa membahas organ dan sistem organ, dengan aspek penilaian yang sama pada pertemuan pertama. Berdasarkan Tabel 1 dapat diketahui bahwa persentase ranah afektif pada kelas eksperimen 1, 2, dan 3 berturut turut 88,46\%; 88,24\%, dan 86, 54\% mencapai kriteria baik dan sangat baik pada saat pengamatan.

Pada penilaian psikomotorik hal yang dinilai adalah (1) kemampuan siswa dalam mengajukan pertanyaan; (2) kemampuan siswa dalam menjawab pertanyaan; (3) kemampuan siswa dalam mengemukakan menemukan jawaban (5) kemampuan dalam mempresentasikan hasil diskusi (6) ketepatan menarik kesimpulan.

Penilaian dilakukan sebanyak dua kali yang kemudian dirata-rata menjadi nilai akhir. Penilaian pertama saat siswa membahas mengenai sel dan jaringan, sedangkan penilaian kedua saat siswa membahas mengenai organ dan sistem organ. Berdasarkan Tabel 2 didapatkan hasil pembelajaran psikomotorik pada eksperimen 1, 2, dan 3 
berturut-turut $86,54 \% ; 86,27 \%$; dan $84,62 \%$ mencapai kriteria baik dan sangat baik pada saat pengamatan. Secara umum siswa kelas eksperimen lebih aktif dalam pembelajaran, mereka mau mengajukan pertanyaan, menjawab pertanyaan, mengemukakan menemukan jawaban, mempresentasikan hasil diskusi dan mereka umumnya lemah dalam menarik kesimpulan.

Pada penilaian afektif dan psikomotorik ketiga kelas eksperimen telah mencapai indikator keberhasilan yaitu $\geq 85 \%$ siswa memperoleh kriteria baik dan Sangat baik, namun persentase yang diperoleh setiap kelas berbeda-beda walaupun selisihnya tidak terlalu besar. Aktivitas yang tinggi ternyata juga diikuti oleh hasil belajar kognitif yang tinggi pula, hal ini terlihat indikator keberhasilan dari ketiga kelas telah tercapai. Penerapan pendekatan inkuiri melalui belajar penemuan merupakan upaya untuk meningkatkan aktivitas siswa dalam pembelajaran.

Pembelajaran yang berpusat pada siswa ini terlihat siswa aktif dalam mengajukan pertanyaan, menjawab pertanyaan, mengemukakan menemukan jawaban, mempresentasikan hasil diskusi. Wenger dalam Huda (2014), interaksi dengan orang lain dapat membantu individu menjalani proses pembelajaran yang lebih positif. Dengan berdiskusi membantu meningkatkan kolaborasi antar individu. Dampak positif pengajaran berlandaskan inkuiri yang diperlihatkan dengan rata-rata ukuran dampak yang cukup tinggi pada beberapa literatur penelitian memberikan dorongan kuat pada aspek filosofis bahwa keterlibatan secara aktif siswa, kesiapan pendidik, dan ketesediaan sarana prasarana indoor maupun outdoor serta bahan ajar yang memadai merupakan faktor-faktor penting keberhasilan pengembangan pembelajaran IPA di sekolah (Abdurrahman, 2017). Di kesempatan lain Dwikoranto (2011), menyatakan bahwa metode diskusi dapat diterapkan dalam pembelajaran sains untuk melatihkan kepekaan sosial, mengikis intoleransi dan kemampuan analisis kritis dan kreatif dalam memecahkan suatu masalah.

Berdasarkan Tabel 3, hasil uji $\mathrm{F}$ post test menunjukkan bahwa diskusi inkuiri disertai penerapan media PowerPoint berpengaruh terhadap hasil belajar. Selanjutnya diuji lanjut yaitu uji BNT menunjukkan bahwa kelas eksperimen 1, 2, 3 berbeda nyata dengan kelas pembanding. 
Hasil belajar kognitif pada kelas eksperimen lebih baik dan lebih tinggi daripada kelas pembanding, hal ini dipengaruhi oleh berbagai faktor salah satunya yaitu adanya rasa senang dan tertarik selama proses pembelajaran dengan metode diskusi inkuiri disertai penerapan media PowerPoint. Rasa senang siswa muncul karena adanya pengalaman baru yang diterima oleh siswa saat pembelajaran.

Rasa senang siswa dapat memacu motivasi, minat, perhatian, serta aktivitas siswa terbentuk. Menurut Uno (2015, p. 31), mengungkapkan bahwa tanda-tanda seseorang terdapat motivasi belajar adalnya ketertarikan dalam belajar. Motivasi, minat, perhatian dan aktivitas atau keterlibatan siswa dalam proses pembelajaran merupakan beberapa faktor pendukung keberhasilan belajar. Ketertarikan siswa pada pembelajaran yang dilakukan mengakibatkan motivasi dan minat siswa muncul. Motivasi dan minat ini menjadikan siswa menjadi lebih perhatian terhadap pembelajaran yang dilakukan. Materi pelajaran yang tidak mendapat perhatian dari siswa karena penyajiannya tidak menarik akan menimbulkan kebosanan pada diri siswa yang akhirnya mempengaruhi hasil belajar.

Motivasi, minat dan perhatian siswa akan menentukan kesungguhan siswa dalam belajar, apabila pelajaran menarik tidak akan menimbulkan kebosanan pada siswa dalam belajar, sehingga timbul motivasi, minat, dan perhatian. Ketiganya akan menjadikan siswa yang pasif menjadi aktif, dan dengan keaktifan siswa yang tinggi maka akan membangkitkan rasa ingin tahu siswa dalam belajar dan juga secara otomatis akan meningkatkan pemahaman siswa.

Hasil penelitian Hairida (2016), menunjukkan bahwa skor keterampilan inkuiri pada kelas eksperimen lebih tinggi dari pada kelas kontrol, dan memperoleh skor signifikan ketika menggunakan t-test $0,00<0,05$, dimana ada perbedaaan yang nyata keterampilan inkuiri kelas eksperimen dan kontrol. Keterampilan menemukan teori ini sangat baik dalam memahami sebuah teori dan konsep dalam IPA. Keterampilan inkuiri juga sangat baik dalam melibatkan siswa sepenuhnya dalam PBM, sehingga siswa tidak merasa bosan saat proses pembelajaran berlangsung dan memberikan pengalaman baru bagi siswa. Siswa lebih mudah memahami materi karena mereka mencari jawaban sendiri dan dan melihat secara langsung ketika diskusi inkuiri selesai melalui tayangan slide PowerPoint. 
Konsep organisasi kehidupan yang dipelajari oleh siswa bersifat abstrak karena banyak mengkaji struktur benda kecil seperti sel, jaringan, dan organ. Media pembelajaran secara khusus dalam proses belajar adalah proses pembelajaran menjadi lebih jelas dan menarik, sehingga dapat menumbuhkan motivasi dan minat belajar siswa, kemudian metode mengajar akan lebih bervariasi, tidak semata komunikasi verbal melalui penuturan kata-kata oleh guru, sehinggga siswa tidak bosan dan tidak menguras banyak tenaga guru, apalagi bila guru mengajar untuk setiap jam pelajaran, serta bahan pengajaran akan lebih jelas maknanya sehingga lebih mudah dipahami oleh para siswa dan memungkinkan siswa menguasai tujuan pengajaran yang lebih baik sehingga hasil belajar yang diperoleh akan menjadi lebih baik.

Pendapat ini diperkuat oleh Djamarah dan Zain (2002) bahwa alat bantu yang cocok dapat mengkonkritkan masalah yang rumit dan kompleks menjadi seolah-olah sederhana yang memudahkan siswa dalam belajar. Dalam memilih alat bantu yang cocok guru harus memperhatikan beberapa kriteria seperti kesesuaian dengan tujuan, kesesuaian dengan isi bahan pelajaran, mudah diperoleh, sesuai dengan keterampilan guru dalam menggunakan dan kesesuaian dengan daya pikir siswa. Pada tahap ini, guru juga memberikan kesempatan seluas luasnya kepada siswa untuk bertanya apabila ada materi yang belum jelas.

Hasil belajar siswa dipengaruhi oleh faktor dari dalam diri siswa dan faktor yang datang dari luar diri siswa atau faktor lingkungan. Salah satu faktor dalam adalah faktor jasmaniah dan kelelahan. Pembelajaran Biologi pada materi organ dan sistem organ di kelas VII E (eksperimen 1) berlangsung pada jam terakhir, beberapa siswa sudah merasa letih dan kurang bersemangat, kondisi jasmani yang lelah ini memiliki dampak negatif yaitu menurunkan motivasi siswa dalam mengikuti pelajaran. Tubuh yang letih tentunya akan mempersulit siswa dalam berkonsentrasi terhadap pelajaran. Faktor luar juga mempengaruhi keberhasilan siswa dalam belajar, faktor luar yang ditemukan pada kelas eksperimen yaitu $7,7 \%$ siswa kurang menyukai suasana kelas dan $7,1 \%$ siswa justru lebih menyukai metode ceramah daripada metode diskusi inkuiri disertai penerapan media PowerPoint.

Metode ceramah dianggap oleh siswa yang paling mudah diterapkan dan suasana terkesan santai dan tidak ada tekanan. Kelas eksperimen 1 memang sedikit agak berbeda dengan kelas eksperimen 2 dan 3, bahwa di kelas tersebut ditemui beberapa anak 
menjadi trouble maker (melakukan aktivitas lain yang tidak mendukung proses pembelajaran) sehingga konsentrasi terhadap materi pelajaran menurun karena terganggu oleh siswa yang sedang ramai sendiri dan mengganggu teman saat pembelajaran berlangsung.

\section{PENUTUP}

Perolehan ketuntasan hasil belajar afektif dan psikomotorik yaitu $\geq 85 \%$ siswa mencapai kriteria baik dan sangat baik. Analisis data kognitif siswa menggunakan analisis varians, apabila uji $\mathrm{F}$ berbeda signifikan maka dilanjutkan uji Beda Nyata Terkecil (BNT). Hasil uji BNT pada post test menunjukkan bahwa kelas eksperimen berbeda nyata dengan kelas pembanding. Dengan demikian dapat disimpulkan bahwa diskusi inkuiri disertai media PowerPoint efektif diterapkan pada materi organisasi kehidupan pada siswa di kelas VII SMP N 1 Pulokulon.

\section{REFERENSI}

Abdurrahman, A. (2017). Efektivitas dan Kendala Pembelajaran Sains Berbasis Inkuiri terhadap Capaian Dimensi Kognitif Siswa: Meta Analisis. Tadris: Jurnal Keguruan Dan Ilmu Tarbiyah, 2(1), 1-9. https://doi.org/10.24042/tadris.v2i1.1206

Dwikoranto, D. (2011). Aplikasi Metode Diskusi Dalam Mengembangkan Kemampuan Kognitif, Afektif Dan Sosial Dalam Pembelajaran Sains. Jurnal Penelitian Fisika dan Aplikasinya (JPFA), 1(2), 40-49. https://doi.org/10.26740/jpfa.v1n2.p40-49

Hairida, H. (2016). The Effectiveness Using Inquiry Based Natural Science Module with Authentic Assessment to Improve the Critical Thinking and Inquiry Skills of Junior High School Students. Jurnal Pendidikan IPA Indonesia, 5(2), 209-215. https://doi.org/10.15294/jpii.v5i2.7681

Huda, M. (2014). Model-Model Pengajaran dan Pembelajaran (Isu-Isu Metodis dam Paradigmatis) (5th ed.). Yogyakarta: Pustaka Pelajar.

Jalil, M. (2016). Pengembangan Pembelajaran Model Discovery Learning Berbantuan Tips Powerpoint Interaktif pada Materi Interaksi Makhluk Hidup dengan Lingkungan. Refleksi edukatika, 6(2). https://doi.org/10.24176/re.v6i2.604

Jalil, M. (2018). Peningkatan Aktivitas Dan Hasil Belajar Siswa Materi Tsunami Melalui Metode Diskusi Inkuiri Disertai Penerapan Media Powerpoint Pada Siswa Kelas X Smk Roudlotus Saidiyyah. Genetika, 1(1). Retrieved from http://journal.stainkudus.ac.id/index.php/Genetika/article/view/3265

Sujarwo. (2013). Pembelajaran Orang Dewasa (Metode dan Teknik) (1st ed.). Yogyakarta: CV. Venus Gold Press.

Uno, H. (2015). Motivasi \& Pengukurannya: Analisis di Bidang Pendidikan. Jakarta: PT Bumi Aksara.

Sudjana. (1998). Metode Statistika. Bandung: PT Remaja Rosdakarya. 